\title{
Lawful Remedy or Illegal Response? Resolving the Issue of Foreign Subsidization under WTO Law - ERRATUM
}

Victor Crochet and Marcus Gustafsson

(First published online 7 May 2021)

doi:10.1017/S1474745621000045, Published by Cambridge University Press, 1 April 2021.

Keywords: Subsidies; European Union; China; extraterritoriality; WTO

Unfortunately, it is not now possible to remove 'such' from the first sentence of the abstract in the online article version or the forthcoming printed edition.

The publisher apologizes for this.

\section{Reference}

Crochet, V. and M. Gustafsson (2021) 'Lawful Remedy or Illegal Response? Resolving the Issue of Foreign Subsidization Under WTO Law'. World Trade Review 1-24. https://doi.org/10.1017/S1474745621000045

Cite this article: Crochet V, Gustafsson M (2021). Lawful Remedy or Illegal Response? Resolving the Issue of Foreign Subsidization under WTO Law - ERRATUM. World Trade Review 20, 381-381. https://doi.org/10.1017/S1474745621000306 (c) The Author(s), 2021. Published by Cambridge University Press 